Poster Section

\title{
Phytopathological and nutraceutical evaluation of cauliflower plants treated with high dilutions of arsenic trioxide
}

\author{
Grazia Trebbi ${ }^{1}$, Giovanni Dinelli ${ }^{1}$, Ilaria Marotti ${ }^{1}$, Valeria Bregola ${ }^{1}$, \\ Maurizio Brizzi ${ }^{2}$, Lucietta Betti ${ }^{1}$
}

\author{
${ }^{1}$ Department of Agroenvironmental Sciences and Technologies, University of Bologna, Italy \\ ${ }^{2}$ Department of Statistical Sciences, University of Bologna, Italy
}

\begin{abstract}
Introduction: This research aimed at verifying the effects of highly diluted (HD) treatments on cauliflower (Brassica oleracea L.) plants both healthy and inoculated by the fungus Alternaria brassicicola, causing the dark leaf spot disease. In vitro spore germination assays (A), growth chamber experiments (B) and field trials (C) were performed.

Material and Methods: (A): spore suspensions were prepared in HD treatments and their inhibiting effect on germination was recorded microscopically after incubation at $25^{\circ} \mathrm{C}$ for $5 \mathrm{~h}$. (B): the same treatments were tested in plants artificially inoculated with the fungus. The infection level on leaves was blindly evaluated by a previously defined infection scale. (C): the field was divided into plots according to a complete randomized block design. In the first trial (i), plants were artificially inoculated and weekly treated; the infection level was evaluated on cauliflower heads. The second trial (ii) was performed on the same field with the aim to induce a natural infection, mediated by infected crop residues. Measurement endpoints concerned the evaluation of some physiological parameters along with the glucosinolate content on cauliflower heads.
\end{abstract}

Results: (A): arsenic trioxide (As 35x and 35x diluted 1:5000) and Cuprum 5x induced highly significant inhibition of germination rate (-60\%) vs. control. (B): As $35 \mathrm{x}$ and $\mathrm{Cu} 3 \mathrm{~g} / \mathrm{l}$ induced a significant decrease of mean infection level (-50\%). (C): in (i), a significant reduction of disease symptoms on heads was recorded for As $35 \mathrm{x}$ and $\mathrm{Cu} 3 \mathrm{~g} / \mathrm{l}$ (-45\%). In (ii) natural fungal infection did not occur due to dry weather conditions; physiological and nutraceutical analyses of healthy heads demonstrated that As 35x induced a significant increase of both head size and glucosinolate content.

Discussion: Some evidences on the efficacy of arsenic, at different decimal and centesimal HD, in fungal and viral disease control were previously reported [1]. In the present study the efficacy of HD arsenic in dark leaf spot control in field has been shown for the first time: since fungal inoculation was performed on the leaves before flowering, we can hypothesize that this treatment induced an increase of plant resistance to fungal infection. 
Conclusions: This research showed the possibility of using HD arsenic in agriculture ("agrohomeopathy"), as it increased both plant resistance to fungal infection and the content of glucosinolates, ie secondary metabolites involved in plant resistance mechanisms [2] and considered as "plant food protection agents" [3].

Acknowledgments: Authors declare there is no conflict of interest. This research has been supported by Marche Region. A grateful acknowledgement to Dr. Leonardo Valenti for his support to this research. The authors thank Laboratoires Boiron srl for the grant awarded to one of the author Dr. Grazia Trebbi. Finally, authors are grateful to Cemon srl for financial support of glucosinolate analyses. We had full access to all the data in this study and we take responsibility for the integrity of the data and the accuracy of the data analysis

Keywords: cauliflower, arsenic trioxide, Alternaria brassicicola, glucosinolates

\section{References}

[1] Betti L, Trebbi G, Majewsky V, Scherr C, Shah-Rossi D, Jäger T, et al. Use of homeopathic preparations in phytopathological models and in field trials: a critical review. Homeopathy 2009; 98: 244-266.

[2] Ménard R, Larue J-P, Silué D, Thouvenot D. Glucosinolates in cauliflower as biochemical markers for resistance against downy mildew. Phytochemistry 1999; 52: 29-35.

[3] Talalay P, Fahey JW. Phytochemicals from Cruciferous plants protect against cancer by modulating carcinogen metabolism. J Nutr. 2001; 131:3027S- 3033S.

\section{(c)) BY-NC-ND Licensed to GIRI}

Support: Marche Region, Laboratoires Boiron srl and Cemon srl.

Conflict of interest: authors declare there is no conflict of interest

Received: 01 June 2012; Revised: 18 August 2012; Published: 30 September 2012.

Correspondence author: Grazia Trebbi, Department of Agroenvironmental Sciences and Technologies, University of Bologna, Bologna, Italy; http://www.dista.unibo.it/, grazia.trebbi@unibo.it

How to cite this article: Trebbi G, Dinelli G, Marotti I, Bregola V, Brizzi M, Betti L. Phytopathological and nutraceutical evaluation of cauliflower plants treated with high dilutions of arsenic trioxide. Int J High Dilution Res [online]. 2012 [cited YYYY Month dd]; 11(40):161-162. Proceedings of the XXVI GIRI Symposium; 2012 Sep 20-22; Florence (Italy). GIRI; 2012; Available from: http://www.feg.unesp.br/ ojs/index.php/ijhdr/article/view/572/573 